\title{
Genetic diversity and molecular survey of Trypanosoma (Megatrypanum) theileri in cattle in Brazil's western Amazon region
}

\author{
Diversidade genética e levantamento molecular de Trypanosoma (Megatrypanum) theileri em bovinos na \\ região da Amazônia Ocidental do Brasil \\ Thábata dos Anjos Pacheco ${ }^{1,2}$; Arlei Marcili ${ }^{3,4}$; Andrea Pereira da Costa ${ }^{3}$; Rute Witter ${ }^{1}$; Andréia Lima Tomé Melo ${ }^{1}$; \\ Ricardo Vilas Boas ${ }^{5}$; Cristiane Silva Chitarra ${ }^{1}$; Valéria Dutra ${ }^{1}$; Luciano Nakazato ${ }^{1}$; Richard de Campos Pacheco ${ }^{1 *}$ \\ ${ }^{1}$ Programa de Pós-graduação em Ciências Veterinárias - PPGVET, Faculdade de Medicina Veterinária - FAVET, Universidade Federal \\ de Mato Grosso - UFMT, Cuiabá, MT, Brasil \\ ${ }^{2}$ Instituto Federal de Rondônia - IFRO, Cacoal, RO, Brasil \\ ${ }^{3}$ Departamento de Medicina Veterinária Preventiva e Saúde Animal, Faculdade de Medicina Veterinária e Zootecnia, Universidade de \\ São Paulo - USP, São Paulo, SP, Brasil \\ ${ }^{4}$ Programa de Pós-graduação em Medicina e Bem-Estar Animal, Universidade de Santo Amaro - UNISA, São Paulo, SP, Brasil \\ ${ }^{5}$ Empresa de Assistência Técnica e Extensão Rural do Estado de Rondônia - EMATER-RO, Ji-Paraná, RO, Brasil
}

Received February 16, 2018

Accepted June 11, 2018

\begin{abstract}
Trypanosoma (Megatrypanum) theileri is a flagellated protozoan that infects ruminants and it displays high genetic diversity. In this study, we investigated the prevalence rates of this protozoan based on hemoculture and molecular diagnosis. The isolates of $T$. theileri thus obtained were characterized by molecular markers SSU rDNA and gGAPDH and molecular diagnosis based on Cathepsin L-like gene (PCR-TthCATL). The PCR-TthCATL and hemoculture indicated an overall prevalence rate of $8.13 \%$, and the CATL derived sequence named IB was identified for the first time in cattle in the western Amazon region, as well as IF in Brazil. We also describe a possible new PCR-TthCATL derived sequence in cattle, designated IL.
\end{abstract}

Keywords: Molecular diagnosis, phylogenetic analysis, hemoculture, Trypanosomatids.

\section{Resumo}

Trypanosoma (Megatrypanum) theileri é um protozoário flagelado que infecta ruminantes e apresenta alta diversidade genética. Neste estudo, investigamos as taxas de prevalência deste protozoário com base na hemocultura e no diagnóstico molecular. Os isolados de T. theileri obtidos foram caracterizados pelos marcadores moleculares SSU rDNA e gGAPDH e o diagnóstico molecular foi baseado no gene do tipo Catepsina L (PCR-TthCATL). O PCR-T thCATL e a hemocultura indicaram uma taxa de prevalência total de $8,13 \%$ e a sequência derivada do gene Catepsina L denominada IB de T. theileri foi identificada pela primeira vez em bovinos da Amazônia Ocidental, bem como a IF no Brasil. Também descrevemos uma possível nova sequência derivada da PCR-TthCATL em bovinos, designada IL.

Palavras-chave: Diagnóstico molecular, análise filogenética, hemocultura, Tripanossomatídeos.

The Trypanosoma theileri Clade, a group of phylogenetically related trypanosomes isolated from ruminants and classified into the subgenus T. (Megatrypanum) (RODRIGUES et al., 2006, 2010a,b), is a complex group of parasites segregated in two lineages (TthI and TthII) that harbor 14 distinct genotypes validated using at least two different molecular markers,

*Corresponding author: Richard de Campos Pacheco. Faculdade de Medicina Veterinária, Universidade Federal de Mato Grosso, Av. Fernando Corrêa da Costa, 2367, Boa Esperança, CEP 78060-900, Cuiabá, MT, Brasil. e-mail: richard@ufmt.br
SSU and ITS rDNA (HAMILTON et al., 2009; LEE et al., 2010; RODRIGUES et al., 2010a,b; GARCIA et al., 2011a,b; FISHER et al., 2013).

In Brazil, the extensive geographical area used for animal husbandry and the intense internal flow of animals favor the contact and transmission of T. theileri and allows genetic events that increase the parasites diversity. Thus, the presence of T. theileri in the Rondônia state (western Amazon region) through hemoculture and molecular diagnosis based on cathepsin L gene were evaluated and the genotypic diversity of $T$. theileri in cattle herds. 
From 2012 and 2013, blood samples were collected from dairy cows ( $\geq 24$ months old) kept by farms in Ji-Paraná (Rondônia state) from six different milk production regions, based on data from the Association of Technical Assistance and Rural Extension of the State of Rondônia - EMATER/RO.

The population size of the study was 34,527 cows from 856 farms; the prevalence rate was estimated to be $50 \%$ (given that there were no previous studies and that the maximum number of occurrences with normal distribution would be at the $50 \%$ mark); maximum error of $6 \%$; $95 \%$ confidence interval (CI); and design effect (deff) of 1.2. The sample size was weighted according to the sampling design, taking into consideration the probabilities of selection among the farms and animals resulting in five animals from each of 64 farms from six different regions (Table 1).

Blood samples were preserved in ethanol (1:1) for molecular analysis. Additional five blood samples were collected from different cows in same farms for trypanosomes isolation (MARCILI et al., 2009a,b) and the isolates were deposited in the Brazilian Trypanosomatid Collection (CBT) at the Department of Preventive Veterinary Medicine and Animal Health, University of São Paulo, São Paulo, Brazil.

DNA from samples of blood preserved in ethanol was purified using the Wizard DNA Clean-Up System (Promega, Madison, USA), while the phenol-chloroform method was to extract DNA from the trypanosome culture samples. DNA from samples of blood preserved in ethanol was subjected to a $T$. theileri-specific PCR assay, based on the Cathepsin L-like (CATL) gene, to screen the DNA samples (RODRIGUES et al., 2010b). Five positive samples that generated the most intense amplified DNA bands were sequenced.

For molecular characterization and phylogenetic studies of T. theileri isolates, the trypanosomatid barcode (V7V8 region of SSU rDNA) was analyzed (SILVA et al., 2004), and glycosomal glyceraldehyde-3-phosphate dehydrogenase (gGAPDH) (HAMILTON et al., 2004). DNA was purified and sequenced in an automated sequencer (ABI-PRISM 3500 Genetic Analyzer, Foster City, CA).

All the sequences thus obtained were aligned with sequences that had previously been determined for other isolates of $T$. theileri available in GenBank, using ClustalX (THOMPSON et al., 1997), and were adjusted manually using GeneDoc (NICHOLAS et al.,
1997). The V7V8 SSU rDNA sequences retrieved from GenBank were AY773674-AY773693, HQ664895-HQ664909, AB007814, GQ176155, and GQ176160, while the sequences for gGAPDH were HQ664784-HQ664806, AJ620282, and FM164792.

The V7V8 SSU rDNA, gGAPDH and CATL sequences were used to build a phylogenetic tree using maximum parsimony, as implemented in PAUP version 4.0 b10 (SWOFFORD, 2002) with 500 bootstrap replicates.

Prevalence on the farms and in dairy cows was calculated with a 95\% CI, using the R statistical package (R DEVELOPMENT CORE TEAM, 2013).

This study was approved by the Bioethical Committee for Animal Research of Federal University of Mato Grosso, under Protocol No. 23108.015662/12-5.

This study resulted in a prevalence of $12.19 \%(95 \%$ CI: 8.91-16.40) among cows tested positive for T. theileri using PCR-TthCATL, while prevalence per herd was 42.19\% (95\% CI: 29.94-55.18\%) (Table 1). Previous studies have reported prevalence rates ranging from $5 \%$ to $26 \%$ by PCR-TthCATL (GARCIA et al., 2011a; SIVAKUMAR et al., 2013; YBAÑEZ et al., 2013; YOKOYAMA et al., 2015). Moreover, it should be noted that the farms in the study area were small, with $56(87.6 \%)$ of them covering less than $100 \mathrm{ha}$, and their proximity to each other may increase the risk of contact with blood-sucking arthropods, which may explain the high inter-herd prevalence rate (42.19\%).

Thirteen isolates were established from the blood culture (CBT 111, CBT 112, CBT 113, CBT 114, CBT 115, CBT 119, CBT 120, CBT 121, CBT 122, CBT 123, CBT 136, CBT 137, and CBT 155), showing a prevalence of 4.06\% (95\% CI: $2.27-7.02 \%)$ and $12.5 \%$ (95\% CI: 5.55-23.15\%) among animals and herd, respectively, and 39 cows tested positive for $T$. theileri using PCR-TthCATL (Table 1). The small number of animals testing positive by hemoculture compared to PCR-TthCATL can be explained by the low parasitemia of $T$. theileri in blood and the higher sensitivity of PCR. This was demonstrated by Rodrigues et al. (2010b), who reported that 34 out of 72 blood samples tested positive by PCR-TthCATL, but only 22 of the same 72 blood samples tested positive by hemoculture.

Therefore, considering the PCR-TthCATL and hemoculture together, the overall prevalence was 8.13\% (95\% CI: 6.18\%-10.59\%), with 52 positive animals, while the herd prevalence rate was

Table 1. Total number of farms, sampled farms, farms testing positive by PCR-TthCATL and hemoculture, total number of cows, sampled cows and cows testing positive by PCR-TthCATL and hemoculture per rural region in the municipality of Ji-Paraná, Rondônia, Brazil.

\begin{tabular}{|c|c|c|c|c|c|c|c|c|}
\hline \multirow{2}{*}{ Region } & \multirow{2}{*}{$\begin{array}{l}\text { No. of } \\
\text { farms }\end{array}$} & \multirow{2}{*}{$\begin{array}{c}\text { No. of } \\
\text { sampled } \\
\text { farms }\end{array}$} & \multicolumn{2}{|c|}{ No. of positives farms } & \multirow{2}{*}{ N. of cows } & \multirow{2}{*}{$\begin{array}{c}\text { No. of } \\
\text { sampled cows }\end{array}$} & \multicolumn{2}{|c|}{ No. of positives cows } \\
\hline & & & PCR-TthCATL & Hemoculture & & & PCR-TthCATL & Hemoculture \\
\hline & & & Positive (\%) & Positive (\%) & & & Positive (\%) & Positive (\%) \\
\hline 1 & 122 & 9 & $2(22.22)$ & $2(4.44)$ & 5246 & 45 & $3(6.67)$ & $2(4.44)$ \\
\hline 2 & 124 & 9 & $7(77.77)$ & $0(0)$ & 5952 & 45 & $10(22.22)$ & $0(0)$ \\
\hline 3 & 54 & 4 & $0(0)$ & $0(0)$ & 2268 & 20 & $0(0)$ & $0(0)$ \\
\hline 4 & 176 & 13 & $8(61.54)$ & $6(45.15)$ & 8096 & 65 & $15(23.08)$ & $11(16.92)$ \\
\hline 5 & 143 & 11 & $3(27.27)$ & $0(0)$ & 4433 & 55 & $3(5.45)$ & $0(0)$ \\
\hline 6 & 237 & 18 & $7(38.89)$ & $0(0)$ & 8532 & 90 & $8(8.89)$ & $0(0)$ \\
\hline Total & 856 & 64 & $27(42.19)$ & $8(12.5)$ & 34527 & 320 & $39(12.19)$ & $13(4.06)$ \\
\hline
\end{tabular}


46.88\% (95\% CI: 34.28-59.77\%), with 30 farms testing positive for T. theileri.

A phylogenetic analysis based on traditional markers (SSU rDNA and gGAPDH genes) allowed the T. theileri isolates from western Amazon to be divided into two genotypes, namely TthIB (86\% and $83 \%$ bootstrap to SSU rDNA and gGAPDH, respectively) and TthIIB (100\% and $93 \%$ bootstrap to SSU rDNA and gGAPDH, respectively) (Figure 1 and Table 2 ).

This is the first report of genotype TthIB in Brazil's western Amazon region. Previous studies in the Amazon have described
A (SSUrDNA)

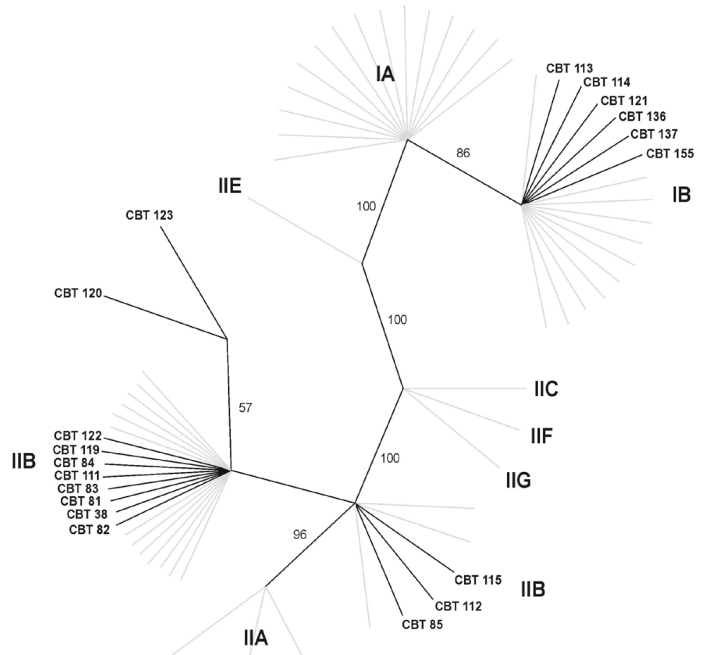

B (gGAPDH)

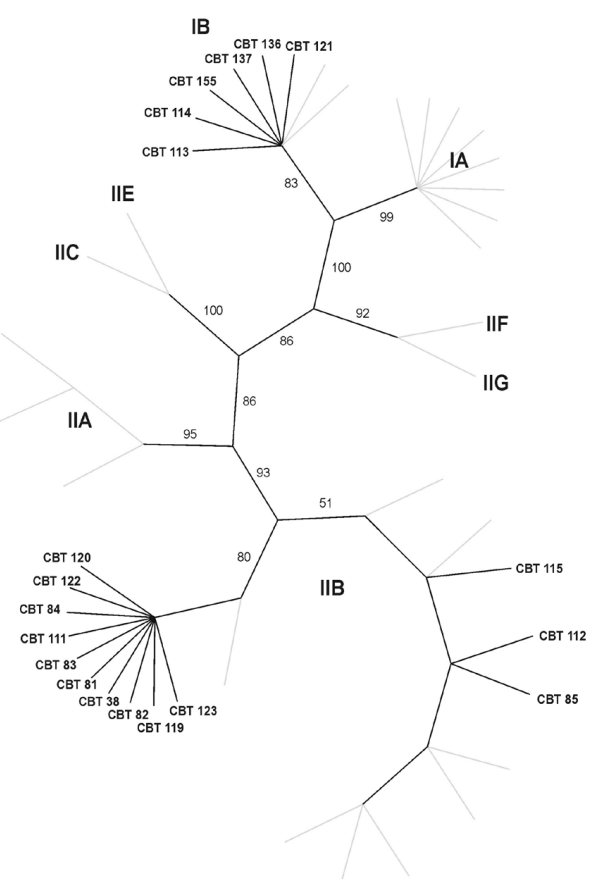

C (CAT-L)

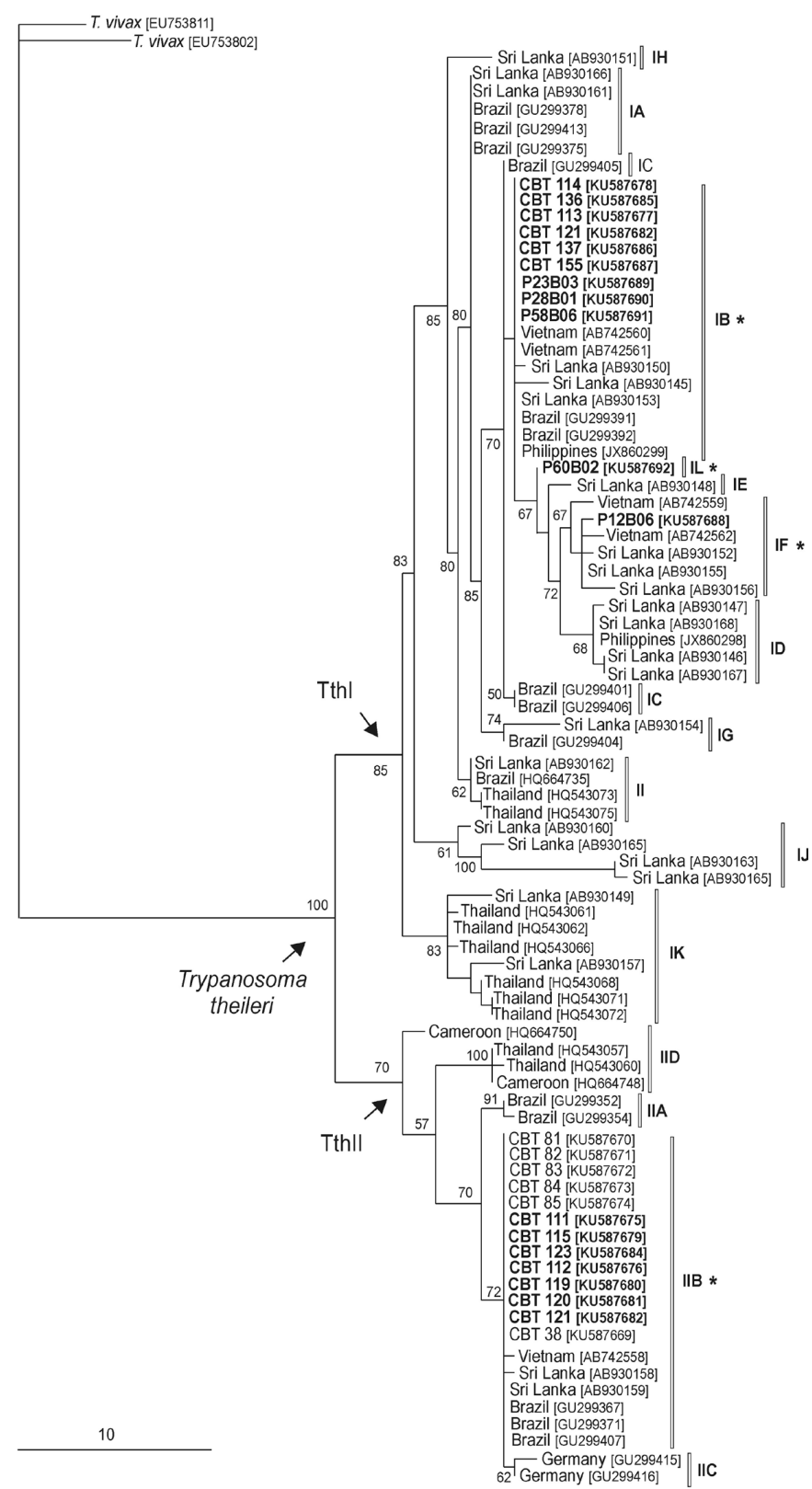

Figure 1. Phylogenetic trees inferred by maximum parsimony. Numbers at nodes are the support values for the major branches (bootstrap or posterior probability) derived, respectively, from 500 replicates for MP. A, V7V8 SSU rDNA gene (712 characters; 18 parsimony-informative sites); B, gGAPDH gene (655 characters; 71 parsimony-informative sites); C, Cathepsin L-like (CAT-L) gene (347 characters; 203 parsimony-informative sites). Trypanosoma vivax was used as outgroup of cathepsin L-like gene analysis. 
Table 2. Trypanosoma isolates, blood samples, genotypes identification and GenBank accession numbers for sequences of CATL, SSU rDNA and gGAPDH genes generated in the present study.

\begin{tabular}{|c|c|c|c|c|c|c|}
\hline \multirow{2}{*}{$\begin{array}{c}\text { Trypanosoma } \\
\text { theileri isolates and } \\
\text { blood samples }\end{array}$} & \multicolumn{3}{|c|}{$\begin{array}{c}\text { Genotypes and CATL derived sequence based on DNA } \\
\text { sequences }\end{array}$} & \multicolumn{3}{|c|}{ GenBank accession numbers } \\
\hline & CATL & SSU rDNA & gGAPDH & CATL & SSU rDNA & gGAPDH \\
\hline CBT 111 & IIB & IIB & IIB & KU587675 & KU587637 & KU587656 \\
\hline CBT 112 & IIB & IIB & IIB & KU587676 & KU587638 & KU587657 \\
\hline СBТ 113 & IB & IB & IB & KU587677 & KU587639 & KU587658 \\
\hline CBT 114 & IB & IB & IB & KU587678 & KU587640 & KU587659 \\
\hline CBT 115 & IIB & IIB & IIB & KU587679 & KU587641 & KU587660 \\
\hline CBT 119 & IIB & IIB & IIB & KU587680 & KU587642 & KU587661 \\
\hline CBT 120 & IIB & IIB & IIB & KU587681 & KU587643 & KU587662 \\
\hline CBT 121 & IIB & IIB & IIB & KU587682 & KU587644 & KU587663 \\
\hline CBT 122 & IB & IB & IB & KU587683 & KU587645 & KU587664 \\
\hline CBT 123 & IIB & IIB & IIB & KU587684 & KU587646 & KU587665 \\
\hline СBТ 136 & IB & IB & IB & KU587685 & KU587647 & KU587666 \\
\hline СBT 137 & IB & IB & IB & KU587686 & KU587648 & KU587667 \\
\hline CBT 155 & IB & IB & IB & KU587687 & KU587649 & KU587668 \\
\hline P12B06 & IF & - & - & KU587688 & - & - \\
\hline Р23B01 & IB & - & - & KU587689 & - & - \\
\hline Р23B03 & IB & - & - & KU587690 & - & - \\
\hline P58B06 & IB & - & - & KU587691 & - & - \\
\hline Р60B02 & IL & - & - & KU587692 & - & - \\
\hline
\end{tabular}

the occurrence of isolates belonging to lineage II in Venezuela (Yarucuy and Cojedes States) and Brazil, where genotype TthIIB was detected in the state of Rondonia, while genotypes TthIIA and TthIIB were observed in the state of Pará (RODRIGUES et al., 2010a; GARCIA et al., 2011b).

Five CATL DNA derived sequences from blood samples (P12B06, P23B01, P23B03, P58B06 and P60B02) were allocated to IB genotype. However, the cattle blood sample P12B06 also disclosed a CATL derived sequence that clustered with Asiatic cattle samples as IF ( $0.18 \%$ of divergence). The blood sample P60B02 disclosed a single CATL derived sequence that might represent a new group of sequence and was herein identified as IL (Figure 1 and Table 2). Only direct samples were grouped with CATL derived sequences IF and IL presenting low divergence to IB, $3.7 \%$ and $0.88 \%$, respectively. All sequences of $T$. theileri obtained in this study were deposited in GenBank and the accession numbers are listed in Table 2.

The genotype IF, identified in this study for the first time in Brazil, had previously been detected in blood samples from cattle in Sri Lanka and Vietnam (SIVAKUMAR et al., 2013; YOKOYAMA et al., 2015). Besides that, a possible new group of CATL derived sequences was identified (IL). The inclusion of sequences in unexpected genotypes IF and IL warn for new studies in poorly studied areas in Brazil. The sequences with the greatest differences are related to sequences obtained from the direct products of the diagnostic PCR and it was not possible to obtain the other markers of these animals.

The genotypic diversity of $T$. theileri is more effectively evidenced when using polymorphic markers such as ITS, SL or CATL. Traditional markers (gGAPDH and SSU rDNA) are more conserved and do not evidence all $T$. theileri genotypes
(RODRIGUES et al., 2003, 2006). In addition, blood culture can select genotypes of parasites with better growth in axenic culture media (RODRIGUES et al., 2003; MARCILI et al., 2013).

Concatenated analysis of one or more markers increases the reliability in phylogenetic trees (MARCILI et al., 2009c; GARCIA et al., 2011b), but the topologies generated by isolated markers such as SL or CATL are congruent to analyzes based on up to six markers. Another important fact is the number of CATL gene sequences deposited in the GenBank that do not have the other markers for the same animals or isolates. In this way, the absence of other markers for the sequences positioned in the IF and IL genotypes with the CATL gene does not disqualify the existence of such genotypes in Brazil, but aim that new studies related to the isolation and characterization of $T$. theileri.

In other Trypanosoma species with high genetic diversity, such as T. cruzi, the concatenated analyzes of several genes make the analyzes more robust, but the phylogeny generated through traditional markers (V7V8 SSU rDNA) is able to segregate all strains and evidence a new Lineage (TCbat) (MARCILI et al., 2009a,b,c).

In this way, the diversity of $T$. theileri has not been fully described, even in countries such as Brazil that has several studies carried out. The inclusion of new sequences from regions not studied in the already known panel of $T$. theileri will contribute to the description of the diversity of this parasite.

In conclusion, the present study describes the IB and IF group of sequences for the first time in cattle in Brazil's western Amazon region, expanding the known geographic distribution and genetic diversity of the agent. Furthermore, the discovery of a possible new group of CATL derived sequence of $T$. theileri, called IL, was described in cattle. 


\section{Acknowledgements}

The authors gratefully acknowledge CNPq (National Council for Scientific and Technological Development) for the awarding a research productivity grant to L. Nakazato, R.C. Pacheco and V. Dutra.

\section{References}

Fisher AC, Schuster G, Cobb WJ, James AM, Cooper SM, Peréz de León AA, et al. Molecular characterization of Trypanosoma (Megatrypanum) spp. infecting cattle (Bos taurus), white-tailed deer (Odocoileus virginianus), and elk (Cervus elaphus canadensis) in the United States. Vet Parasitol 2013; 197(1-2): 29-42. http://dx.doi.org/10.1016/j.vetpar.2013.04.037. PMid:23683651.

Garcia HA, Kamyingkird K, Rodrigues AC, Jittapalapong S, Teixeira MMG, Desquesnes M. High genetic diversity in field isolates of Trypanosoma theileri assessed by analysis of cathepsin L-like sequences disclosed multiple and new genotypes infecting cattle in Thailand. Vet Parasitol 2011a; 180(3-4): 363-367. http://dx.doi.org/10.1016/j. vetpar.2011.03.017. PMid:21477926.

Garcia HA, Rodrigues AC, Martinkovic F, Minervino AHH, Campaner M, Nunes VLB, et al. Multilocus phylogeographical analysis of Trypanosoma (Megatrypanum) genotypes from sympatric cattle and water buffalo populations supports evolutionary host constraint and close phylogenetic relationships with genotypes found in other ruminants. Int J Parasitol $2011 \mathrm{~b}$; 41(13-14): 1385-1396. http://dx.doi.org/10.1016/j.ijpara.2011.09.001. PMid:22051399.

Lee YF, Cheng CC, Lin NN, Liu SA, Tung KC, Chiu YT. Isolation of Trypanosoma (Megatrypanum) theileri from dairy cattle in Taiwan. J Vet Med Sci 2010; 72(4): 417-424. http://dx.doi.org/10.1292/jvms.09-0343. PMid:20009352.

Hamilton PB, Stevens JR, Gaunt MW, Gidley J, Gibson WC. Trypanosomes are monophyletic: evidence from genes for glyceraldehyde phosphate dehydrogenase and small subunit ribosomal RNA. Int J Parasitol 2004; 34(12): 1393-1404. http://dx.doi.org/10.1016/j.ijpara.2004.08.011. PMid:15542100.

Hamilton PB, Adams ER, Njiokou F, Gibson WC, Cuny G, Herder S. Phylogenetic analysis reveals the presence of Trypanosoma cruzi clade in African terrestrial mammals. Infect Genet Evol 2009; 9(1): 81-86. http:// dx.doi.org/10.1016/j.meegid.2008.10.011. PMid:19027884.

Marcili A, Costa AP, Soares HS, Acosta IC, Lima JT, Minervino AH, et al. Isolation and phylogenetic relationships of bat trypanosomes from different biomes in Mato Grosso, Brazil. J Parasitol 2013; 99(6): 1071-1076. http://dx.doi.org/10.1645/12-156.1. PMid:23859496.

Marcili A, Lima L, Cavazzana M, Junqueira AC, Veludo HH, Maia Da Silva F, et al. A new genotype of Trypanosoma cruzi associated with bats evidenced by phylogenetic analyses using SSU rDNA, cytochrome b and Histone H2B genes and genotyping based on ITS1 rDNA. Parasitology 2009a; 136(6): 641-655. http://dx.doi.org/10.1017/S0031182009005861. PMid:19368741.

Marcili A, Valente VC, Valente SA, Junqueira ACV, Silva FM, Pinto AYN, et al. Trypanosoma cruzi in Brazilian Amazonia: Lineages TCI and TCIIa in wild primates, Rhodnius spp. and in humans with Chagas disease associated with oral transmission. Int J Parasitol 2009b; 39(5): 615-623. http://dx.doi.org/10.1016/j.ijpara.2008.09.015. PMid:19041313.
Marcili A, Lima L, Valente VC, Valente SA, Batista JS, Junqueira AC, et al. Comparative phylogeography of Trypanosoma cruzi TCIIc: new hosts, association with terrestrial ecotopes, and spatial clustering. Infect Genet Evol 2009c; 9(6): 1265-1274. http://dx.doi.org/10.1016/j. meegid.2009.07.003. PMid:19632356.

Nicholas KB, Nicholas HB Jr, Deerfield DW. GeneDoc: analysis and visualization of genetic variation. Embnew News 1997; 4: 14.

R Development Core Team. A language and environment for statistical computing [online]. Vienna: R Foundation for Statistical Computing; 2013 [cited 2017 Nov 30]. Available from: http://www.R-project.org.

Rodrigues AC, Campaner M, Takata CS, Dell' Porto A, Milder RV, Takeda GF, et al. Brazilian isolates of Trypanosoma (Megatrypanum) theileri: diagnosis and differentiation of isolates from cattle and water buffalo based on biological characteristics and randomly amplified DNA sequences. Vet Parasitol 2003; 116(3): 185-207. http://dx.doi.org/10.1016/ S0304-4017(03)00236-X. PMid:14559162.

Rodrigues AC, Paiva F, Campaner M, Stevens JR, Noyes HA, Teixeira MMG. Phylogeny of Trypanosoma (Megatrypanum) theileri and related trypanosomes reveals lineages of isolates associated with artiodactyl hosts diverging on SSU and ITS ribosomal sequences. Parasitology 2006; 132(Pt 2): 215-224. http://dx.doi.org/10.1017/S0031182005008929. PMid:16197590.

Rodrigues AC, Garcia HA, Ortiz PA, Cortez AP, Martinkovic F, Paiva F, et al. Cysteine proteases of Trypanosoma (Megatrypanum) theileri: cathepsin L-like gene sequences as targets for phylogenetic analysis, genotyping diagnosis. Parasitol Int 2010a; 59(3): 318-325. http://dx.doi. org/10.1016/j.parint.2010.03.002. PMid:20230907.

Rodrigues AC, Garcia HA, Batista JS, Minervino AH, Goés-Cavalcante G, Maia da Silva F, et al. Characterization of spliced leader genes of Trypanosoma (Megatrypanum) theileri: phylogeographical analysis of Brazilian isolates from cattle supports spatial clustering of genotypes and parity with ribosomal markers. Parasitology 2010b; 137(1): 111-122. http://dx.doi.org/10.1017/S0031182009991053. PMid:19765336.

Silva FM, Noyes H, Campaner M, Junqueira AC, Coura JR, Añez N, et al. Phylogeny, taxonomy and grouping of Trypanosoma rangeli isolates from man, triatomines and sylvatic mammals from widespread geographical origin based on SSU and ITS ribosomal sequences. Parasitology 2004; 129(Pt 5): 549-561. http://dx.doi.org/10.1017/S0031182004005931. PMid:15552400.

Sivakumar T, Lan DTB, Long PT, Yoshinari T, Tattiyapong M, Guswanto A, et al. PCR detection and genetic diversity of bovine hemoprotozoan parasites in Vietnam. J Vet Med Sci 2013; 75(11): 1455-1462. http:// dx.doi.org/10.1292/jvms.13-0221. PMid:23856762.

Swofford DL. PAUP: Phylogenetic analysis using parsimony. Beta Version 4.0610. Sunderland: Sinauer and Associates. 2002.

Thompson JD, Gibson TJ, Plewniak F, Jeanmougin F, Higgins DG. The CLUSTAL_X windows interface: flexible strategies for multiple sequence alignment aided by quality analysis tools. Nucleic Acids Res 1997; 25(24): 4876-4882. http://dx.doi.org/10.1093/nar/25.24.4876. PMid:9396791.

Ybañez AP, Sivakumar T, Ybañez RHD, Vincoy MRB, Tingson JA, Perez ZO, et al. Molecular survey of bovine vector-borne pathogens in Cebu, Philippines. Vet Parasitol 2013; 196(1-2): 13-20. http://dx.doi. org/10.1016/j.vetpar.2013.02.013. PMid:23499481.

Yokoyama N, Sivakumar T, Fukushi S, Tattiyapong M, Tuvshintulga B, Kothalawala H, et al. Genetic diversity in Trypanosoma theileri from Sri Lankan cattle and water buffaloes. Vet Parasitol 2015; 207(3-4): 335341. http://dx.doi.org/10.1016/j.vetpar.2014.12.006. PMid:25554063. 